\title{
PEMBERIAN SUSU PENGGANTI TERHADAP PENINGKATAN BERAT BADAN HARIAN CEMPE LEPAS SAPIH
}

\author{
Martinus Alexander*1, Arnanda Padang Rachmasari ${ }^{2}$, Retno Sri Wahjuni3, Sunaryo \\ Hadi Warsito ${ }^{3}$, M. Gandul Atik Yuliani ${ }^{3}$ \\ ${ }^{1}$ Peternakan Edufarm Desa Jatijejer Kecamatan Trawas Kabupaten Mojokerto \\ ${ }^{2}$ Mahasiswa Fakultas Vokasi Universitas Airlangga Surabaya \\ ${ }^{3}$ Staf Pengajar Fakultas Kedokteran Hewan Universitas Airlangga Surabaya \\ e-mail: gandulatik@yahoo.com
}

\begin{abstract}
Abstrak
Pemberian pakan merupakan unsur yang sangat menentukan pertumbuhan, reproduksi dan kesehatan ternak, sehingga penambahan kadar protein dalam ransum akan dapat meningkatkan bobot badan ternak, salah satu usaha untuk meningkatkan kandungan protein pakan adalah dengan pemberian nutrisi pakan imbuhan berupa susu pengganti atau Calf Milk Replacer (CMR) pada cempe masa pasca sapih disamping pemberian pakan konsentrat dan hijauan. Penelitian ini bertujuan untuk melihat pengaruh pemberian susu pengganti terhadap peningkatan berat badan harian (PBBH). Pengamatan ini menggunakan 10 ekor cempe Boer lepas sapih yang dibagi menjadi dua kelompok perlakuan. Perlakuan pertama yaitu dengan pemberian susu pengganti dan perlakuan kedua tanpa pemberian susu pengganti. Kemudian penimbangan berat badan berkala selama satu bulan. Hasil yang didapatkan menunjukkan peningkatan berat badan harian cempe lepas sapih dengan pemberian susu pengganti yaitu sekitar 0,031 kg dan untuk cempe tanpa pemberian susu pengganti yaitu sekitar 0,03 kg. Kesimpulan yang dapat ditarik bahwa Peningkatan berat badan harian cempe lepas sapih yang diberikan susu pengganti tidak berbeda dengan yang tidak diberikan susu pengganti. Disarankan agar lebih memperhatikan komposisi dari susu pengganti.
\end{abstract}

Kata kunci-susu pengganti, peningkatan berat badan harian, cempe Boer

\begin{abstract}
Feeding is an element that determines the growth, reproduction and health of livestock, so that the addition of protein content in the ration will be able to increase the body weight of livestock, one of the efforts to increase the protein content of feed is by providing supplementary nutrition in the form of replacement milk or Calf Milk Replacer (CMR) in post-weaning lamb besides feeding concentrated and forage feeds. This study aims to look at the effect of substituting milk on daily weight gain. This observation uses 10 Boer lamb which are divided into two treatment groups. The first treatment is by giving milk substitutes and the second treatment without giving milk substitutes. Then weighing periodically for one month. The results showed that the daily weight gain of weaned lamb by replacing milk was around $0.031 \mathrm{~kg}$ and for lamb without replacement milk was around $0.03 \mathrm{~kg}$. The conclusion that can be drawn is that the daily increase in weaning weight of lamb off weaning milk substitutes is no different from those not given milk replacements. It is recommended to pay more attention to the composition of milk substitutes.
\end{abstract}

Keywords-replacement milk, daily weight gain, Boer lamb 


\section{PENDAHULUAN}

Kenaikan laju pertumbuhan penduduk disertai dengan tingkat pengetahuan dan pendapatan masyarakat yang semakin membaik menyebabkan meningkatnya permintaan akan pangan berprotein tinggi terutama dari produk peternakan, khususnya daging. Salah satu ternak ruminansia kecil yang berpotensi sebagai penghasil daging adalah ternak kambing. (Nurgiartiningsih, 2011)

Perkembangan bangsa kambing di dunia mengarah kepada tiga produk utama yaitu daging, susu dan bulu (mohair). Oleh karena kemampuan adaptasinya yang sangat baik terhadap berbagai keragaman klimat, maka terdapat beberapa bangsa kambing yang menyebar di berbagai zona agroekosistem. Diperkirakan ada sebanyak 102 bangsa kambing yang menyebar di seluruh dunia dengan bobot hidup yang sangat beragam dari yang terkecil antara $9-13 \mathrm{~kg}$ sampai terbesar melebihi $100 \mathrm{~kg}$ (Dhanda et al., 2003a).

Faktor kualitas daging kambing, terutama dalam kaitannya dengan isu kesehatan maupun gizi yang sebenarnya memiliki keunggulan komparatif dibandingkan dengan daging asal ternak lain, selama ini belum banyak disosialisasikan kepada masyarakat. Keunggulan kualitas daging kambing ini seharusnya dapat menjadi salah satu faktor pendorong penting bagi peningkatan konsumsi daging kambing nasional.

Kambing Boer adalah salah satu jenis kambing unggul penghasil daging yang didatangkan ke Indonesia. Keunggulan genetik yang dimiliki kambing Boer adalah pertumbuhan cepat, mudah beradaptasi pada berbagai kondisi lingkungan, mempunyai kualitas daging yang bagus sesuai dengan konformasi tubuhnya, serta mempunyai sifat reproduksi yang baik (Van Niekerk dan Casey, 1988).

Kambing Boer telah dikenal luas dalam hal keunggulannya menghasilkan daging baik dari sisi jumlah maupun karakteristik kimiawinya. Kapasitas bobot hidup dan laju pertumbuhan kambing Boer menunjukkan potensi tersebut. Bobot hidup pejantan Boer dewasa yang terseleksi dengan baik (improved Boer) dapat mencapai antara 100 - $120 \mathrm{~kg}$ dan berat sapih umur 120 hari dapat mencapai $29 \mathrm{~kg}$ (Malan, 2000). Erasmus (2000) melaporkan bobot lahir kambing Boer mencapai 3,9-4,0 kg dan pada umur 100 hari pejantan Boer setelah dikoreksi terhadap tipe kelahiran rata-rata mencapai $25,3 \mathrm{~kg}$, sedangkan ratarata laju pertambahan bobot badan harian berkisar antara 20,3-24,5 g.

Susu pengganti diformulasi dari berbagai produk samping industri susu, bahan pakan, pakan imbuhan. Umumnya susu skim merupakan komponen utama penyusun susu pengganti untuk anak kambing (Suprijati, 2014). Selain sebagai sumber energi, susu skim juga digunakan sebagai sumber protein, dimana kandungan proteinnya sebesar $45 \%$ (Chester 2011). Bila ditinjau dari segi nutrisi pemberian pakan merupakan unsur yang sangat menentukan pertumbuhan, reproduksi dan kesehatan ternak, sehingga penambahan kadar protein dalam ransum akan dapat meningkatkan bobot badan ternak (Mulyono, 2005). Secara ekonomis, pemberian susu pengganti berdampak pada meningkatnya pendapatan (Keskin \& Biçer 2002; Budiarsana et al. 2013) dikarenakan susu kambing lebih mahal daripada susu pengganti.

Edufarm Kambing Burja menerapakan pemberian nutrisi pakan imbuhan berupa susu pengganti atau Calf Milk Replacer $(C M R)$ pada cempe masa pasca sapih disamping pemberian pakan konsentrat dan hijauan. Tujuan pemberian susu pengganti tersebut adalah untuk menunjang peningkatan berat badan harian $(\mathrm{PBBH})$.

\section{TINJAUAN PUSTAKA}

\subsection{Karakteristik Kambing Boer}

Kambing Boer adalah salah satu kambing unggul dan pertama kali dibudidayakan di Afrika Selatan pada tahun 1900-an untuk produksi daging. Nama 
kambing ini berasal dari bahasa Belanda yang berarti petani. Kambing Boer umumnya bertubuh putih dan kepala warna coklat. Kambing ini bertubuh lebar, panjang, berkaki pendek, berhidung cembung, dan bertelinga panjang menggantung. Kambing unggul ini terkenal jinak, pertumbuhannya cepat, dan tingkat kesuburannya tinggi. Kambing Boer jantan dewasa berumur 2-3 tahun dapat mencapai bobot badan antara 110-135 kg, dan kambing Boer betina dewasa antara 90-100 kg. Pertambahan bobot badan rata-rata $0,02-0,04 \mathrm{~kg} / \mathrm{hari}$. Persentase daging pada karkas kambing Boer jauh lebih tinggi dibanding kambing lainnya dan mencapai 40\%-50\% dari berat tubuhnya (Anonimous, 2008).

Menurut Ted dan Shipley (2008), bahwa kambing Boer jantan bertubuh kokoh dan kuat, pundaknya luas dan bagian belakangnya dipenuhi dengan otot yang padat. Kambing Boer dapat hidup pada suhu lingkungan yang ekstrim, mulai dari suhu sangat dingin $\left(-25^{\circ} \mathrm{C}\right)$ hingga sangat panas $\left(43^{\circ} \mathrm{C}\right)$ dan mudah beradaptasi terhadap perubahan suhu lingkungan. Kambing ini juga tahan terhadap penyakit dan dapat hidup di kawasan semak belukar, lereng gunung yang berbatu atau di padang rumput.

Ditambahkan oleh Ted dan Shipley (2008), bahwa secara alamiah kambing ini adalah hewan yang suka meramban sehingga lebih menyukai dedaunan, rumput berdaun lebar, dan tanaman semak dari pada rumput biasa. Kambing Boer jantan senang kalau digaruk dan digosok di bagian belakang telinga, punggung dan sisi perutnya. Kambing jenis ini mudah ditangani dengan memegang tanduknya dan juga dapat dilatih dituntun dengan tali.

\subsection{Pemeliharaan Cempe}

Kesehatan anak kambing dapat dijaga dengan memberikan cukup kolostrum yang berasal dari induknya, sanitasi dan ruangan berventilasi baik dan hindari kepadatan. Perhatian dan kecermatan harus dilakukan pada saat pemberian pakan padat. (Suprijati, 2014)

Ternak sebelum disapih, ditransisikan dengan memberikan susu 1-
2 kali sehari. Setelah disapih, selanjutnya ternak diberi pakan padat dan hijauan.

2.3 Peningkatan Berat Badan Harian

Pertumbuhan adalah proses peningkatan ukuran tulang, otot, organ dalam dan bagian tubuh lain. Pertambahan bobot badan dinyatakan dalam ukuran kenaikan bobot badan dengan melakukan penimbangan berulang-ulang dalam kurun waktu tertentu yaitu setiap hari, minggu atau bulan (Handayani, 2005).

Pertambahan bobot badan merupakan salah satu peubah yang dapat digunakan untuk menilai kualitas bahan makanan ternak. Pertambahan bobot badan yang diperoleh dari percobaan pada ternak merupakan hasil dari zat-zat makanan yang dikonsumsi, sehingga dari data pertambahan bobot badan akan diketahui nilai suatu pakan bagi ternak (Warhani, 2006).

Perlu diketahui bahwa ternak ruminansia mempunyai keterbatasan dalam mengkonsumsi ransum. Hijauan atau rumput yang ada di Indonesia (dengan iklim tropis) relatif cepat tumbuh tetapi kandungan gizinya rendah. Oleh karena itulah ternak yang hanya diberikan hijauan tanpa adanya tambahan pakan lain berupa konsentrat tidak mungkin mencapai penambahan bobot badan yang tinggi. Disamping faktor genetik dan jenis kelamin, tinggi rendahnya pertambahan bobot badan yang dicapai terutama sangat bergantung pada pakan yang diberikan (Siregar, 2007).

\subsection{Susu Pengganti}

Susu pengganti diformulasi dari berbagai produk samping industri susu, bahan pakan, pakan imbuhan (vitamin, mineral, enzim dan asam amino). Untuk kondisi dalam negeri dimana terbatasnya (jumlah dan varians) produk samping industri susu maka dalam memformulasi susu pengganti perlu strategi sesuai dengan ketersediaan dan harga bahan baku tersebut. (Suprijati, 2014). 
Komposisi nutrien susu pengganti terutama protein, lemak dan laktosa untuk setiap jenis susu berbeda, untuk itu dalam menyusun susu pengganti terformulasi sebaiknya disusun sesuai dengan jenis ternak yang akan mengkonsumsinya. Umumnya susu pengganti yang diimpor dan tersedia di pasaran dalam negeri, diformulasi dari $60-75 \%$ tepung susu skim, 15-25\% lemak nabati atau hewani, $5-10 \%$ tepung butter milk atau protein hasil samping industrikeju.

\section{METODE PENELITIAN}

Pengamatan ini menggunakan 10 ekor cempe Boer lepas sapih yang dibagi menjadi dua kelompok perlakuan. Perlakuan pertama yaitu dengan pemberian susu pengganti dan perlakuan kedua tanpa pemberian susu pengganti. Kemudian penimbangan berat badan berkala selama satu bulan.

Metode yang digunakan adalah sebagai berikut.

\section{Pemberian Susu}

Untuk kelompok cempe dengan pemberian susu pengganti di Edufarm Kambing Burja dilaksanakan sebanyak dua kali sehari yaitu pada pagi hari pukul 09.00 dan sore hari pukul 16.00. Porsi harian individu yaitu satu liter dalam dua kali pemberian. Pengeceran susu sebanyak 125 gram susu pengganti per $500 \mathrm{ml}$ air hangat. Pemberian susu pengganti melalui botol susu berputing (nipple) dan dalam keadaan tidak terlalu dingin atau terlalu panas.

\section{Pengukuran Berat Badan}

Metode pengukuran berat badan cempe yang dilakukan di Edufarm Kambing Burja tersebut dengan cara menimbang dengan timbangan gantung jarum. Timbangan terlebih dahulu harus digantungkan ke suatu tempat agar pengait timbangan bisa difungsikan untuk menggantungkan tali tambang. Sebelumnya, tali tambang dapat di lingkarkan ke badan cempe lalu digantungkan di pengait sehingga badan cempe terangkat menggantung. Kemudian, untuk mengetahui berat badan cempe yang ditimbang, dilihat dari jarum yang menunjuk pada satuan angka timbangan (dalam kilogram). Penimbangan berat badan cempe Boer ini dilakukan tiap minggu selama satu bulan.

\section{Analisa Data}

Data yang diperoleh dari penimbangan berat badan dicatat tiap minggu, selanjutnya dianalisis secara deskriptif. Analisis deskriptif digunakan untuk mengetahui gambaran data yang akan dianalisiskan dan disajikan dalam bentuk diagram tabel.

\section{HASIL DAN PEMBAHASAN}

Bahan penyusun susu pengganti umumnya digunakan bahan aditif yang tersedia di pasaran dan diformulasikan sesuai dengan kebutuhan nutrienya. Bahan penyusun utama susu pengganti antara lain: Susu skim, mengandung laktosa sebagai sumber energi, dan sumber protein sebesar 45 $\%$ (Chester 2011), konsentrat rotein kedelai 60-70\%, (Sampelayo et al. (1995), protein limbah industri keju 35\%, (Galina et al. (1995), tepung jagung dan tepung terigu memiliki karbohidrat tinggi dan serat yang rendah sehingga baik sebagai sumber energi, (Bañón et al. (2006), lemak hewani dan minyak nabati sebagai sumber energi. (Krishnamoorthy \& Moran 2011).

Sumber protein susu untuk cempe berumur diatas 3 minggu sebagian dapat digantikan oleh protein nonsusu. Sumber protein nonsusu adalah konsentrat protein kedelai, tepung kedelai, gluten gandum terhidrolisis, tepung terigu, dimana kandungannya tidak lebih dari $15 \%$. (Krishnamoorthy \& Moran 2011) 
Jurnal Biosains Pascasarjana Vol. 21 (2019) pp

(C) (2019) Sekolah Pascasarjana Universitas Airlangga, Indonesia

Tabel.1 Hasil Uji Analisis Proksimat Susu Pengganti yang Digunakan di Edufarm dan Rekomendasi Nutrien Susu

\begin{tabular}{|c|l|c|}
\hline $\begin{array}{c}\text { Kandungan } \\
\text { Nutrisi }\end{array}$ & $\begin{array}{l}\text { Hasil } \\
\text { Analisis } \\
\text { Susu } \\
\text { Pengganti } \\
(\%)\end{array}$ & $\begin{array}{l}\text { Rekomendas } \\
\text { i nutrien } \\
\text { Susu } \\
\text { Pengganti } \\
(\%)\end{array}$ \\
\hline $\begin{array}{c}\text { Bahan } \\
\text { Kering }\end{array}$ & 96,30 & - \\
\hline Abu & 3,37 & - \\
\hline $\begin{array}{c}\text { Protein } \\
\text { Kasar }\end{array}$ & 13,56 & $18,00-2,00$ \\
\hline $\begin{array}{c}\text { Lemak Kasar } \\
\text { Serat Kasar }\end{array}$ & 6,74 & $-20,00$ \\
\hline Ca & 9,47 & 1,00 \\
\hline BETN & 71,88 & - \\
\hline $\begin{array}{c}\text { ME } \\
\text { Kcal/kg })\end{array}$ & 3583,68 & $3760-4740$ \\
\hline Penggan & & \\
\hline
\end{tabular}

Pengganti.

Susu pengganti di Edufarm Kambing Burja diberikan dengan pengenceran sebanyak 125 gram susu dan $500 \mathrm{ml}$ air panas (1:4). Susu diaduk hingga homogen lalu di angin-anginkan sampai suhu susu turun menjadi hangat. Pemberian melalui botol susu bernipple untuk mencegah kembung pada cempe.

\section{Perbedaan Pemberian Susu}

\section{Pengganti Pada Dua Kelompok Perlakuan}

Di Edufarm Kambing Burja cempe yang telah mencapai umur kurang lebih 70 hari akan dilepas sapih induk dan dipindah ke kandang pemeliharaan khusus lepas sapih. Cempe lepas sapih diberi susu pengganti pada pagi hari pukul 09.00 dan sore hari pukul 16.00 sebagai pakan tambahan, disamping pemberian pakan konsentrat dan hijauan. Pakan konsentrat diberikan sebanyak 700 gram per ekor/hari dalam dua kali pemberian pagi hari pukul 07.30 dan sore hari pukul14.30. Pakan hijauan silase diberikan sebanyak $2 \mathrm{~kg}$ per ekor/hari.
Pada pengamatan Praktek Kerja Lapangan ini, digunakan 10 ekor cempe Boer lepas sapih yang dibagi menjadi dua kelompok perlakuan dengan pemberian susu pengganti dan tanpa pemberian susu pengganti. Perbedaan perlakuan ini bertujuan untuk melihat pengaruh pakan tambahan susu pengganti dalam meningkatkan berat badan harian cempe lepas sapih melalui hasil pengukuran berat badan cempe selama satu bulan.

Tabel 2 Kelompok Cempe Lepas Sapih Dengan dan Tanpa Pemberian Susu Pengganti

\begin{tabular}{|c|c|c|c|c|c|}
\hline No & $\begin{array}{l}\text { Tang } \\
\text { gal } \\
\text { Lahir }\end{array}$ & $\begin{array}{l}\text { Umur } \\
\text { (hari) }\end{array}$ & $\begin{array}{l}\text { Ear } \\
\text { Tag }\end{array}$ & $\begin{array}{c}\mathrm{Se} \\
\mathrm{x}\end{array}$ & $\begin{array}{l}\text { Pemberia } \\
\text { susu } \\
(\mathrm{ml} / \mathrm{h})\end{array}$ \\
\hline 1 & $\begin{array}{l}03 / 12 \\
/ 2019\end{array}$ & $\begin{array}{l}6 \\
9\end{array}$ & $\begin{array}{l}\text { BRJ } \\
002\end{array}$ & JTN & 1000 \\
\hline 2 & $\begin{array}{l}21 / 11 \\
/ 2019\end{array}$ & $\begin{array}{l}8 \\
1\end{array}$ & $\begin{array}{c}\text { F3 } \\
002\end{array}$ & JTN & 1000 \\
\hline 3 & $\begin{array}{l}21 / 11 \\
/ 2019\end{array}$ & $\begin{array}{l}8 \\
1\end{array}$ & $\begin{array}{c}\text { F3 } \\
003\end{array}$ & JTN & 1000 \\
\hline 4 & $\begin{array}{l}28 / 11 \\
/ 2019\end{array}$ & $\begin{array}{l}7 \\
4\end{array}$ & $\begin{array}{c}\mathrm{SO} \\
\mathrm{Kb} \\
1067\end{array}$ & JTN & 1000 \\
\hline 5 & $\begin{array}{l}28 / 11 \\
/ 2019\end{array}$ & $\begin{array}{l}7 \\
4\end{array}$ & $\begin{array}{c}\mathrm{Kb} \\
1064\end{array}$ & BTN & 1000 \\
\hline 6 & $\begin{array}{l}02 / 12 \\
/ 2019\end{array}$ & $\begin{array}{l}7 \\
0\end{array}$ & $\begin{array}{c}\mathrm{Kb} \\
106 \\
5\end{array}$ & BTN & ( \\
\hline 7 & $\begin{array}{l}05 / 12 \\
/ 2019\end{array}$ & $\begin{array}{l}6 \\
7\end{array}$ & $\begin{array}{c}\mathrm{Kb} \\
107 \\
4\end{array}$ & BTN & ( \\
\hline 8 & $\begin{array}{l}06 / 12 \\
/ 2019\end{array}$ & $\begin{array}{l}6 \\
6\end{array}$ & $\begin{array}{c}\mathrm{Kb} \\
107 \\
7\end{array}$ & BTN & ( \\
\hline 9 & $\begin{array}{l}08 / 12 \\
/ 2019\end{array}$ & $\begin{array}{l}6 \\
4\end{array}$ & $\begin{array}{c}\mathrm{Kb} \\
108 \\
8\end{array}$ & JTN & ( \\
\hline 10 & $\begin{array}{l}08 / 12 \\
/ 2019\end{array}$ & $\begin{array}{l}6 \\
4\end{array}$ & $\begin{array}{c}\text { OS } \\
\text { F4 } \\
006\end{array}$ & BTN & ( \\
\hline
\end{tabular}

Berdasarkan pengamatan didapatkan hasil dari pengukuran berat badan tiap individu yang dilakukan secara konsisten tepat satu minggu sekali menggunakan timbangan gantung jarum. Peningkatan 
berat badan tiap cempe berbeda-beda tiap minggunya mulai dari yang cukup signifikan, stabil dan lambat. Hal tersebut dapat dipengaruhi oleh berbagai macam perbedaan kondisi dalam seminggu sebelum pengukuran berat badan yang dimiliki masing-masing cempe antara lain: kondisi kesehatan, banyak pakan yang dikonsumsi dan tingkat stres.

Berdasarkan tabel 3 dapat disimpulkan bahwa dalam satu bulan rata-rata kenaikan berat badan per individu cempe lepas sapih dengan pemberian susu pengganti yaitu 0,94 $\mathrm{kg}$ dan rata-rata kenaikan berat badan per individu cempe lepas sapih tanpa pemberian susu pengganti yaitu $0,90 \mathrm{~kg}$. Kemudian peningkatan berat badan harian cempe lepas sapih dengan pemberian susu pengganti yaitu sekitar 0,031 $\mathrm{kg}$ dan untuk cempe tanpa pemberian susu pengganti yaitu sekitar $0,03 \mathrm{~kg}$. Hasil peningkatan berat badan harian kedua kelompok perlakuan tersebut sesuai dengan pendapat Ted dan Shipley (2005) yaitu rataan pertambahan berat tubuh antara 0,02 - 0,04 kg per hari

Tabel 3. Jumlah Peningkatan Berat Badan Total Tiap Minggu Per

\begin{tabular}{|c|c|c|c|c|c|c|c|c|}
\hline Perlakuan & \multicolumn{4}{|c|}{$\begin{array}{l}\text { Pemberian Susu } \\
\text { pengganti }\end{array}$} & \multicolumn{4}{|c|}{$\begin{array}{c}\text { Tanpa } \\
\text { Pemberian } \\
\text { susu } \\
\text { pengganti }\end{array}$} \\
\hline $\begin{array}{c}\text { Umur } \\
\text { pengukuran } \\
\text { (Minggu) }\end{array}$ & 1 & 2 & 3 & 4 & 1 & 2 & 3 & 4 \\
\hline $\begin{array}{c}\text { Peningkatan } \\
\text { Berat } \\
\text { Badan }(\mathrm{Kg})\end{array}$ & 1,3 & 1,3 & 1,2 & 0,9 & 0,9 & 1,2 & 1,3 & 1,1 \\
\hline $\begin{array}{l}\text { Total } \\
\text { Peningkatan } \\
\text { Berat Badan } \\
(\mathrm{Kg})\end{array}$ & \multicolumn{4}{|c|}{4,7} & \multicolumn{4}{|c|}{4,5} \\
\hline $\begin{array}{l}\text { Rataan } \\
\text { Peningkatan } \\
\text { Berat Badan } \\
(\mathrm{Kg})\end{array}$ & \multicolumn{4}{|c|}{0,94} & \multicolumn{4}{|c|}{0,90} \\
\hline
\end{tabular}

Individu.

\section{KESIMPULAN DAN SARAN}

Berdasarkan hasil yang diperoleh dari pengamatan ini maka dapat disimpulkan bahwa:

Peningkatan berat badan harian cempe lepas sapih yang diberikan susu pengganti tidak berbeda dengan yang tidak diberikan susu pengganti.

Susu Pengganti yang digunakan sebagai pakan tambahan, memiliki kandungan nutrisi yang tidak mendukung untuk mengoptimalkan peningkatan berat badan cempe lepas sapih, yang bisa disebabkan dari komposisi dan jenis bahan penyusun susu pengganti.

\section{DAFTAR PUSTAKA}

Abrams E, Guthrie P, Harris B. 2010. Effect of dry matter intake from whole goat milk and calf milk replacer on performance of Nubian goat kids. J Dairy Sci. 68:1748-1751.

Bañón S, Vila R, Price A, Ferrandini E, Garrido MD. 2006. Effects of goat milk or milk replacer diet on meat quality and fat composition of suckling goat kids. Meat Sci. 72:216-221

Budiarsana, I.G.M. dan I.K, Sutama. 1995. Karakteristik Produktivitas Kambing Peranakan Etawah. Lokakarya Nasional Pengelolaan dan Perlindungan Sumber Daya Genetik di Indonesia: Manfaat Ekonomi untuk Mewujudkan Ketahanan Nasional. Balai Penelitian Ternak Bogor: 215-220.

Chester W. 2011. Nutritionalcomposition of skim milk powder. National Institute for Health and Welfare [Internet]. Available from: www.fineli.fi/food.php

Darmadi, D. 2004. Produktivitas Ternak Pedaging di Dua Desa yang Berbeda Ketinggian Tempat di Kabupaten Garut.Skripsi Fakultas Peternakan Institut Pertanian Bogor, Bogor 
Jurnal Biosains Pascasarjana Vol. 21 (2019) pp

(C) (2019) Sekolah Pascasarjana Universitas Airlangga, Indonesia

Dhanda, J.S., D.G. TAYLOR, P.J. MURRAY, R.B. PEGG and P.J. Shand. 2003a."Goat meat production: Present status and Future Possibilities." AsianAust. J. Anim. Sei. 16: 1842 - 1852.

Erasmus, J.A. 2000. Adaptation to various environments and resistance to disease of improved Boer goat. Small Rumin. Res. 36: $179-187$.

Galina MA, Palma JM, Pacheco D, Morales R. 1995. Effect of goat milk, cow milk, cow milk replacer and partial substitution of the replacer mixture with whey on artificial feeding of female kids. Small Rumin Res. 17:153-158.

Handayani V. P. 2005. Kecernaan dan Penggunaan Pakan Untuk Pertambahan Bobot Badan Walabi Betina (Dorcopsulus vanheurni ) Di Penangkaran.

Hart S, Delaney C. 2011. Husbandry of dairy animals: goat replacement management. In: Fuquay J, Fox P, McSweeney P, editors. Encycl Dairy Sci. 2nd ed. Oxford (UK): Elsevier. p. 825-833.

Keskin M, Biçer O. 2002. Effects of milk replacer on kid growth and farm profitability in the Shami goat. Turkish J Vet Anim Sci. 26:1133-1136

Krishnamoorthy U, Moran J. 2011. Rearing young ruminants on milk replacers and starter feeds. In: Makkar HPS, editor. Animal Production and Health Manual No. 13. Rome (Italy): FAO.

Li RW, Sparks ME, Conner, Erin E. 2011. Dynamic of the rumen microbiota. In: Li RW, editor. Metagenomics its Appl Agric Biomed Environ Stud. New York (US): Nova Science Publishers, Inc. p. $135-164$

Lubis, D. A. 1992. Ilmu Makanan Ternak. PT. Pembangunan. Jakarta.

Ted dan Shipley L. 2005 Mengapa Harus Memelihara Kambing Boer "Daging Untuk Masa Depan". Malang. Indonesia. http://kambing- sapiunggul.blogspot.com/2008/12

O'Brien A. 1998. Nutrition of the young goat: birth to breeding. Ontario (Canada): Minister of Agriculture, Food and Rural Affairs.

\section{APPENDIX}

NB: PANJANG JURNAL 13 - 15 HALAMAN. 